\title{
Views on the quality of life of people with disabilities in the light of their involvement in sport activities
}

\author{
Remigiusz Dróżdż \\ Gdansk University of Physical Education and Sport, Gdansk, Poland
}

abstract

Background: The quality of life of people with disabilities is the result of many factors. Apart from health, functional and mental parameters, it is determined by several social conditions. This approach, however, concerns an objective perspective, apart from which there is also a subjective perspective. This is an internal approach that affects the sense of the quality of life, to a limited extent referring to the quality of life itself. Therefore, it can be assumed that the subjective views on the quality of life will be determined by the location in the social context, an example of which is sport activity. The aim of the research was to find out the opinions of disabled athletes about the quality of life in the context of their participation in various forms of physical activities.

Material and methods: The research analysis was conducted on 107 disabled athletes and 19 disabled non-athletes. A diagnostic survey method was used with a questionnaire technique. The research tool was the Quality of Life Index, an American scale which belongs to the global category of scales and is composed of a series of questions referring to different areas of life.

Results: The results of the survey did not confirm more positive opinions about the quality of life among disabled athletes. The differences between the groups turned out to be statistically insignificant in most cases.

Conclusions: Since most of the research results to date indicate a positive impact of regular physical activity on selfesteem and the quality of life, it seems necessary to explore this problem on a larger research sample of people with disabilities.

Key words: people with disabilities, quality of life, sport activity.

\section{article details}

Article statistics: Word count: 2,307; Tables: 2; Figures: 0; References: 32

Received: June 2020; Accepted: August 2020; Published: November 2020

Full-text PDF: http://www.balticsportscience.com

Copyright @ Gdansk University of Physical Education and Sport, Poland

Indexation: Celdes, Clarivate Analytics Emerging Sources Citation Index (ESCl), CNKI Scholar (China National Knowledge Infrastructure), CNPIEC, De Gruyter - IBR (International Bibliography of Reviews of Scholarly Literature in the Humanities and Social Sciences), De Gruyter - IBZ (International Bibliography of Periodical Literature in the Humanities and Social Sciences), DOAJ, EBSCO - Central \& Eastern European Academic Source, EBSCO - SPORTDiscus, EBSCO Discovery Service, Google Scholar, Index Copernicus, J-Gate, Naviga (Softweco, Primo Central (ExLibris), ProQuest - Family Health, ProQuest - Health \& Medical Complete, ProQuest - Illustrata: Health Sciences, ProQuest - Nursing \& Allied Health Source, Summon (Serials Solutions/ProQuest, TDOne (TDNet), Ulrich's Periodicals Directory/ulrichsweb, WorldCat (OCLC)

Funding: This research received no specific grant from any funding agency in the public, commercial, or not-for-profit sectors.

Conflict of interests: Corresponding author: Author has declared that no competing interest exists.

Remigiusz Dróżdż, Gdansk, University of Physical Education and Sport, Gorskiego 1 St., 80-336 Gdańsk, Poland; e-mail: remigiusz.drozdz@awf.gda.pl

Open Access License:

This is an open access article distributed under the terms of the Creative Commons Attribution-Non-Commercial-NoDerivatives 4.0 International (https://creativecommons.org/licenses/by-nc-nd/4.0/), which permits use, distribution and reproduction in any medium, provided the original work is properly cited, the use is non-commercial and is otherwise in compliance with the license. 


\section{INTRODUCTION}

There are over 650 million people with disabilities in the world, which is less than $10 \%$ of the world's population [1]. People with severe or moderate disabilities constitute $5 \%$ of the population in less developed regions of the world and 7\% in more developed regions. 60 million people with disabilities live in China, including 11 million with physical disabilities [2].

The last decades have become more and more promising in the context of the strategy of activating and integrating disabled people [3]. This is the right answer on the structural and social level, giving an opportunity to change their difficult life situation [4]. At the same time, there is a chance to break the stereotypes defining this social group as weak and fearful people, and thus unable to function fully in society [5]. Conservative, and sometimes even reluctant attitudes towards the disabled are the result of high ranking in the hierarchy of importance of features theoretically not related to disability, such as success, strength, wealth, independence, health and physical fitness [6]. For this reason, there is an urgent need for action to normalize the lives of people with disabilities [7]. Undoubtedly, an important element of the policy of including disabled people in social structures is their activation through sport $[8,9]$. However, it is advisable that this type of activities is supported by the non-disabled members of the population [10] and promoted through the media [11-13].

One of the most famous pioneers of sport for people with physical disabilities, Ludwig Guttmann pointed to the key role of sport in their activation [14], considering it an effective means of restoring contact with the outside world. This integration, in the sense of more effective contact with the non-disabled, can be discussed by analyzing the health and healing function of sport $[15,16]$. The support of the activation process in professional and family fields [17] is also significant [18].

Despite the obvious limitations associated with disability, such a person becomes definitely more functional in the physical [19] and mental sense [20-22]. Thus, this favors meeting the needs of the individual necessary from the point of view of their proper physical, social and mental development [23].

Considered as the precursor of research on the quality of life, an American researcher, Angus Campbell assumes that the quality of life consists of the degree of satisfaction in predetermined areas of life such as: marriage, family life, health, neighbors, friends, housework, work, life in a given country, place of residence, free time, housing conditions, education and standard of living [24]. According to Ferrans and Powers, quality of life is the well-being, which is determined by satisfaction with those areas of life that are important to an individual [25]. Quality of life is an interdisciplinary concept that researchers in the fields of medicine, psychology, sociology, philosophy, and social economy deal with [26]. Quality of life of people with disabilities is the subject of numerous scientific studies that represent 3 independent trends. One of them includes works of authors who point out the differences between the quality of life of disabled and non-disabled people [27]. The second trend involves comparative analyses of the quality of life between different groups of people with disabilities [28, 29]. The third trend comprises works describing methods to improve the quality of life of people with disabilities. It is often based on experimental verification of different, own-elaborated methods of quality of life improvement [30-32].

The approach to the quality of life of disabled athletes, despite the undoubted research input of the already cited Tomasz Tasiemski, has so far received fewer references in scientific literature, hence the need to explore this issue. The main research goal was to find out the opinions of disabled athletes about the quality of life in the context of their participation in various forms of physical activities. 


\section{MATERIAL AND METHODS}

To achieve the above-mentioned goal, the following research question was stated: Is playing sports a variable among the disabled which differentiates views on the quality of own life in the groups of people practicing and not practicing sports. A hypothesis was adopted that a higher level of the quality of life assessment will be observed more often in the group of disabled athletes than among disabled persons who do not engage in sports activities.

Over 150 questionnaires were collected from disabled athletes, of which those that were not completed correctly were rejected. Finally, 107 sets of surveys completed by this research group were analyzed. The number of examined disabled people not involved in sports was 19 .

Quality of Life Index (QLI) is an American scale developed by Ferrans and Powers [25], established for the quantitative assessment of the quality of life. It belongs to the global scales category and is composed of a set of questions about specific areas of life. This scale includes weighing the spheres of life by applying an indicator of the importance of individual spheres for the examined person. It has been shown that the use of this procedure significantly changes the measurement results.

The theoretical basis of QLI refers to the definition of the quality of life as a sense of satisfaction or dissatisfaction arising from those areas of life that are important to the individual. The scale is divided into two parts containing 33 items. The first part measures satisfaction with various areas of life, while the second part measures the importance of these areas for the individual. The answer is given according to a systematic rank system (both in terms of measuring satisfaction and determining validity) which consists of a 6-step scale of estimates, like the Likert scale:

1. Extremely dissatisfied

2. Very dissatisfied

3. Somewhat dissatisfied

4. Somewhat satisfied

5. Very satisfied

6. Extremely satisfied

The result is the outcome of weighing the degree of satisfaction with the corresponding level of importance of the areas covered. The quality of life index enables global quality of life assessment as well as a scoring of the following subscales: health and functioning, social and economic, family, psychological/spiritual. The possible range of global and partial scores is from -15 to 15, with higher scores for better quality of life. All QLI survey items are considered when calculating the total score, which reflects the overall (global) quality of life.

\section{Quality of Life Index - Health and Functioning Subscale}

The assessment of health and functioning situation of the examined person is based on questions related to the following aspects of life:

1. health

2. health care

3. pain

4. energy (fatigue)

5. ability to take care of yourself

6. control over life

7. chances for living as long as you would like

8. sex life

9. ability to take care of family responsibilities

10. usefulness to others

11. worries 
12. things for fun

13. chances for a happy future

\section{Quality of life - Social and Economic Subscale}

The assessment of the socio-economic situation of the examined person is based on questions related to the following aspects of life:

1. friends

2. emotional support from your friends

3. neighborhood

4. home

5. job / not having a job

6. education

7. financial needs

\section{Quality of Life Index - Psychological/Spiritual Subscale}

The assessment of the psychological and spiritual situation of the examined person is based on questions related to the following aspects of life:

1. peace of mind

2. faith in God

3. achievement of personal goals

4. happiness in general

5. life satisfaction in general

6. personal appearance

7. self

\section{Quality of Life Index - Family Subscale}

The assessment of the family subscale of the examined person is based on questions related to the following aspects of life
1. family health
2. children
3. family happiness
4. spouse or partner
5. emotional support from family

Data analysis was carried out using the StatSoft, Inc. program. STATISTICA (data analysis software system), version 12 . The analysis of interdependence of qualitative features was carried out using the Pearson chi-squared test. The statistical hypothesis was verified assuming a level of significance of 0.05 . Groups homogeneous in terms of the analyzed variables were determined using the following tests: Scheffe when parametric methods were used, and multiple comparisons when nonparametric methods were used (failure to meet assumptions about the normality of distributions in groups). Nonparametric methods become useful when, as in this sample, uneven groups are encountered: experimental and control (with a statistically significant difference). In such a case, the data still have significant analytical potential, and uneven group sizes are not a problem in terms of statistical analysis.

\section{RESULTS}

Based on the results obtained within each subscale: pain, partner and sex, health and functioning, social and economic, psychological and spiritual as well as family surveyed non-athletes were assigned to clusters of quality of life designated for disabled athletes. Most of the disabled non-sportsmen turned out to belong to a higher quality of life concentration. The detailed results are presented in the table below. 
Table 1. Adherence of the surveyed disabled athletes and non-athletes to designated clusters of quality of life

\begin{tabular}{|c|c|c|c|c|}
\hline \multirow{2}{*}{ No. } & \multirow{2}{*}{ Disabled people group } & \multicolumn{2}{|c|}{ Quality of life } & \multirow{2}{*}{ Sum } \\
\hline & & lower level & higher level & \\
\hline 1 & Number of athletes & 58 & 49 & 107 \\
\hline 2 & Percentage of athletes & 54.2 & 45.8 & \\
\hline 3 & Number of non-athletes & 5 & 14 & 19 \\
\hline 4 & Percentage of non-athletes & 26.3 & 73.7 & \\
\hline 5 & Total & 63 & 63 & 126 \\
\hline
\end{tabular}

The surveyed non-disabled athletes significantly more often belonged to the group with a higher declared quality of life $\left(\chi^{2}=5.02, \mathrm{p}=0.025\right)$; in this group almost 3 out of 4 respondents belonged to the cluster with a higher quality of life, while in the group of disabled athletes less than one in two respondents belonged to this cluster.

Table 2. The mean values, standard deviation or median and quarter deviation of the components of the Quality of Life Index divided into categories of lower or higher quality of life and sports for the disabled

\begin{tabular}{|c|c|c|c|c|c|c|c|c|}
\hline \multirow{3}{*}{ Quality of Life Index Item } & \multicolumn{2}{|c|}{$\begin{array}{c}\text { lower level of quality } \\
\text { of life }\end{array}$} & \multicolumn{2}{|c|}{$\begin{array}{c}\text { higher level of quality } \\
\text { of life }\end{array}$} & \multicolumn{4}{|c|}{ homogenous groups ${ }^{1)}$} \\
\hline & $\begin{array}{c}\text { athletes } \\
\quad\{1\}\end{array}$ & $\begin{array}{l}\text { non- } \\
\text { athletes } \\
\{2\}\end{array}$ & $\begin{array}{c}\text { athletes } \\
\{3\}\end{array}$ & $\begin{array}{c}\text { non- } \\
\text { athletes } \\
\{4\}\end{array}$ & $\{1\}$ & $\{2\}$ & $\{3\}$ & $\{4\}$ \\
\hline & $\bar{x} \pm S D$ & $\bar{x} \pm S D$ & $\bar{x} \pm S D$ & $\bar{x} \pm S D$ & & & & \\
\hline Social and economic & $0.8 \pm 2.9$ & $0.7 \pm 3.1$ & $6.9 \pm 3.7$ & $7.7 \pm 3.8$ & $*$ & $*$ & $* *$ & ** \\
\hline Subscale of QLI & $m e \pm Q D$ & $m e \pm Q D$ & $m e \pm Q D$ & $m e \pm Q D$ & & & & \\
\hline Pain & $-2 \pm 3.5$ & $-4.5 \pm 4$ & $-2.5 \pm 5.6$ & $-2 \pm 5.8$ & $*$ & $*$ & $*$ & $*$ \\
\hline Partner and sex & $0.5 \pm 2.8$ & $-5.5 \pm 1.6$ & $8.3 \pm 3.8$ & $9 \pm 1.9$ & $*$ & $*$ & $* *$ & ** \\
\hline Health and functioning & $0.8 \pm 1.8$ & $3.5 \pm 3.4$ & $7 \pm 2.1$ & $7.1 \pm 1.9$ & $*$ & $* *$ & ** & $* *$ \\
\hline Psychological and spiritual & $0.9 \pm 1.5$ & $1.5 \pm 1.9$ & $7.3 \pm 1.6$ & $8.1 \pm 1$ & $*$ & $*$ & ** & ** \\
\hline Family & $2.3 \pm 3.1$ & $1.5 \pm 0.1$ & $9 \pm 2.8$ & $9.6 \pm 2.6$ & $*$ & $*$ & $* *$ & $* *$ \\
\hline
\end{tabular}

1) the columns of the table homogeneous groups contain information which of the examined subgroups do not differ statistically significantly in terms of the analyzed variable (belonging to the same group marked with the symbol * or **).

What is worth emphasizing in each of the clusters of quality of life, the surveyed nonathletes did not significantly differ from disabled athletes in each of the subscales, e.g. in the clustering of lower quality of life by comparing the results of e.g. the "family" subscale, athletes did not differ significantly from non-athletes. Similarly, in the higher clustering the quality of life for the "family" subscale athletes did not differ significantly from non-athletes (Table 2).

Furthermore, for each of the subscales, with the exception of the variable "pain", the principle of existence of significant differences between groups of athletes and non-athletes from the focus of lower quality of life with the results of groups of athletes or non-athletes from the focus of higher quality of life was maintained.

The only exception to this rule was the results of disabled non-athletes on the "health and functioning" subscale. Disabled athletes from the lower quality of life clustering achieved significantly lower scores on the "health and functioning" subscale from both disabled athletes and non-athletes from the higher quality of life clustering. Meanwhile, disabled non-athletes from a lower quality of life clustering did not differ significantly from disabled athletes from their clustering, but they did not differ significantly from athletes and nonathletes from a higher quality of life clustering. For the "pain" variable, there were no significant differences between the analyzed subgroups. 


\section{CONCLUSIONS}

The assumption that practicing sport improved the assessment of the quality of life turned out to be wrong in the case of the examined group of disabled people. Undoubtedly, these results require confirmation in the course of subsequent studies. Current research clearly speaks in favor of disabled persons practicing sports. Consideration should be given to expand the surveyed group in future research projects, including especially people with disabilities who do not practice sport. This will probably lead to more convincing conclusions.

For people with disabilities, participation in sport activities is an opportunity to meet the need for self-fulfillment and social acceptance. Not without significance is the fact that fitness obtained through physical activity builds a positive image of the disabled person in his own eyes and in the eyes of other people. Thus, limiting social stigmatization and enhancing development potential should become a source of positive experiences for people with disabilities who practice sport. This kind of activity reduces negative emotions associated with disabilities in the form of depression, anxiety, or shame. This conclusion is true even more considering that in the Polish reality disabled athletes in recent years have provided at least as many positive surprises than the healthy ones. It often seems that their commitment and determination are greater, because in addition to sports improvement, they must constantly overcome the limitations resulting from their own disability. Presumably, because of this, for some of them the subjective conviction about the quality of their lives suffers.

\section{REFERENCES}

[1] Pagán R. Time allocation in tourism for people with disabilities. Ann Tourism Res. 2012;39(3):1514-1537. https:// doi.org/10.1016/j.annals.2012.04.005

[2] Bi Y, Card J, Cole S. Accessibility and attitudinal barriers encountered by Chinese travelers with physical disabilities Int J Tourism Res. 2007;9(3):205-216. https://doi.org/10.1002/jtr.603

[3] Buhalis D, Darcy S, Ambrose I. Best practices in accessible tourism. inclusion, disability, ageing population and tourism. Ontario: Channel View Publications; 2012. https://doi.org/10.21832/9781845412548

[4] Kryńska E. Analiza sytuacji osób niepełnosprawnych w Polsce i Unii Europejskiej. Raport przygotowany w ramach projektu „Zatrudnienie osób niepełnosprawnych- perspektywy wzrostu” [Analysis of the situation of disabled people in Poland and the European Union. Report prepared under the project "Employment of disabled people - growth prospects"]. Warszawa: IPiSS; 2013. Polish.

[5] Czykwin E, Rusaczyk M. Gorsi inni - badania [Worse others - research]. Białystok: Wydawnictwo Uniwersyteckie Trans Humana; 2008.Polish.

[6] Kossewska J. Społeczeństwo wobec osób niepełnosprawnych - postawy i ich determinanty [Society towards people with disabilities - attitudes and their determinants]. Studia Psychologica. 2003;14:1-11. Polish.

[7] Niedbalski J. Sport osób niepełnosprawnych w przekazie i dyskursie medialnym w Polsce [Sports of disabled people in the message and media discourse in Poland]. Przegląd Socjologii Jakościowej. 2015;11(2):130-159. Polish.

[8] Barlak M. Pedagogiczne wartości sportu integracyjnego [The pedagogical values of inclusive sport] In: Nowocień J, eds.Społeczno-edukacyjne oblicza olimpizmu. Ruch olimpijski i niepełnosprawni sportowcy [Socio-educational faces of the Olympics. Olympic movement and disabled athletes]. Warszawa: AWF, Polska Akademia Olimpijska; 2006, 141-147. Polish

[9] Łuszczyńska A. Psychologia sportu i aktywności fizycznej. Zagadnienia kliniczne [Psychology of sport and physical activity. Clinical issues].Warszawa: PWN; 2011. Polish.

[10] Tasiemski T. Attitudes, relationships and adjustment In: Bickenbach J, eds. International perspectives on spinal cord injury. Geneva-Switzerland: World Health Organization; 2013, 121-146.

[11] Barnes C. Wizerunek niepełnosprawności i media. Badanie zasad przedstawiania osób niepełnosprawnych w środkach masowego przekazu. [The image of disability and the media. Examination of the principles of representation of people with disabilities in the mass media]. Warszawa: Ogólnopolski Sejmik Osób Niepełnosprawnych; 1997. Polish.

[12] Andrzejewska A, Bednarek J.Osoby niepełnosprawne a media cyfrowe. Z pogranicza teorii i praktyki [People with disabilities and digital media. On the verge of theory and practice]. Warszawa: Wydawnictwo Akademii Pedagogiki Specjalnej; 2010. Polish.

[13] Niedbalski J. Sport jako narzędzie aktywizacji i społecznej integracji osób z niepełnosprawnością fizyczną [Sport as a tool for activation and social integration of people with physical disabilities]. Problemy Polityki Społecznej. Studia i Dyskusje 2015;28(1):101-118. Polish.

[14] Guttmann S. Significance of sport in rehabilitation of spinal paraplegics and tetraplegics. JAMA. 1976;2(236):195-197.

[15] Nigel T, Smith A. Disability, sport and society. London: Tayler \& Francis; 2009.

[16] Tasiemski T, Wilski M, Priebe M. Life satisfaction and life values in people with spinal cord injury living in three Asian countries: a multicultural study. J Spinal Cord Med. 2013;36(2):118-126. https://doi. org/10.1179/2045772312Y.0000000074 
[17] Nowocień J. Społeczno-edukacyjne oblicza olimpizmu. Ruch olimpijski i niepełnosprawni sportowcy [Socio-educationa] faces of the Olympics. Olympic movement and disabled athletes]. Warszawa: AWF, Polska Akademia Olimpijska; 2006. Polish.

[18] Molik B, Morgulec-Adamowicz N, Kosmol A. Zespołowe gry sportowe osób niepełnosprawnych. Koszykówka na wózkach i rugby na wózkach [Sports team games for disabled people. Basketball on wheelchairs and rugby on wheelchairs]. Warszawa: AWF; 2008. Polish.

[19] Dywejko B, Rotter I, Kemicer-Chmielewska E, Karakiewicz B. Porównanie opinii wśród niepełnosprawnych sportowców i studentów Uniwersytetu Szczecińskiego na temat sportu inwalidzkiego [Comparison of opinions among disabled athletes and students of the University of Szczecin on disability sports]. Annales Academiae Medicae Stetinensis. 2014;60(1):88-92. Polish. https://doi.org/10.21164/pomjlifesci.15

[20] Bar-Or O. Health benefits of physical activity during childhood and adolescents. President Council on Physical Fitness and Sports Physical Activity and Fitness Research Digest. 1995 2(4):1-8.

[21] Giannini M. National initiative on physical fitness for children and youth with disabilities. Office on Disability Office of the Secretary U.S. Department of Health and Human Services; 2004.

[22] Wilson P. Exercise and sports for children who have disabilities. Phys Med Rehabil Clinics North America 2012; 13 (4): 907-923. https://doi.org/10.1016/S1047-9651(02)00030-X

[23] Tasiemski T, Kennedy P, Gardner B, Taylor N. The association of sports and physical recreation with life satisfaction in a community sample of people with spinal cord injuries. NeuroRehabilitation. 2005;20:253-265. https://doi. org/10.3233/NRE-2005-20403

[24] Campbell A, Converse P, Rogers W. The quality of American Life: perception, evaluation, and satisfaction. New York: Rasel Sage Foundation; 1976.

[25] Ferrans C, Powers M. Psychometric assessment of the quality of life index. Res Nursing Health. 1992;15:29-38. https://doi.org/10.1002/nur.4770150106

[26] Papuć E. Jakość życia - definicje i sposoby jej ujmowania [Quality of life - definitions and ways of recognizing it].Curr Probl Psychiatry. 2011;12(2):141-145. Polish.

[27] Civan A. The relation between self esteem levels and life quality levels of disabled and non-disabled tennis sportsmen. Education Res Rev. 2015;10:351-356. https://doi.org/10.5897/ERR2014.2025

[28] Altin M. Anger Expression styles of hearing impaired individuals doing sport and those not doing sport. Education Res Rev. 2015;10:2406-2412. https://doi.org/10.5897/ERR2015.2430

[29] Ziółkowski A, Zubrzycki I, Błachnio A, Drobnik P, Zarańska B, Moska W. Influence of sport activity on satisfaction with life and sense of coherence among physically disabled people. Baltic J Health Phys Act. 2016;8:109-116. https:// doi.org/10.29359/BJHPA.08.4.12

[30] Feys P, Tytgat K, Gijbels D, De Groote L, Baert I, Van Asch P. Effects of a 1-day education program on physical functioning, activity and quality of life in community living persons with multiple sclerosis. NeuroRehabilitation. 2013;33:439-448. https://doi.org/10.3233/NRE-130975

[31] Kamelska A, Mazurek K. The assessment of the quality of life in visually impaired people with different level of physical activity. Phys Cult Sport. Stud Res. 2015;67:31-41. https://doi.org/10.1515/pcssr-2015-0001

[32] Sultan B, Malik N, Atta M. Effect of social support on quality of life among orthopedically disabled students and typical students. J. Postgrad. Med. Inst. 2016;30:254-258. 